https://doi.org/10.15407/ujpe65.2.174

N.G. DEBELO, S. HAILEMARIAM

Jimma University, Department of Physics, P. O. Box 378

(Jimma,Ethiopia; e-mail: nebgem.eyu@gmail.com)

\title{
EFFECT OF THERMAL ANNEALING ON THERMOLUMINESCENCE GLOW CURVES OF $\mathrm{KY}_{3} \mathrm{~F}_{10}: \mathrm{Ho}^{3+}$
}

\begin{abstract}
The effect of thermal annealing on thermoluminescence (TL) glow curves of commercially obtained $K Y_{3} F_{10}: \mathrm{Ho}^{3+}$ phosphor is investigated, and the result is compared with that of unannealed sample. The samples were annealed at different annealing temperatures: namely, 400, 500 , and $600{ }^{\circ} \mathrm{C}$. The activation energy (trap depth), which is one of the TL kinetic parameters, is calculated for the annealed and unannealed samples using the variable heating rate (VHR) method. The results show that the thermal annealing has a clear effect on the TL intensities of the glow curves. The maxima of the TL glow curves shift toward a higher temperature region, as the annealing temperature increases. Moreover, the higher the annealing temperature, the shallower the position of the trap beneath the edge of the conduction band. The X-ray diffraction (XRD) pattern of the sample shows a monoclinic structure with unit cell dimensions (in Angström) $a=10.41, b=6.73, c=12.46$ match with JCPDS card No. 21-1458.

Keywords: thermoluminescence, thermal annealing, variable heating rate method, activation energy.
\end{abstract}

\section{Introduction}

Thermoluminescence (TL) technique has reached a new level in the fields of radiation therapy, space research, geology, archaeology, and other related research areas and attracts the attention of a lot of researchers. It is an extremely powerful technique used for the estimation of doses of ionizing radiation, since the energy absorbed during the irradiation and the following TL intensity is proportional to the radiation doses. The TL glow curve is a measure of the intensity of the emitted light as a function of the temperature. A change in the glow curve, i.e., a change in TL peaks, leads to a change in trap parameters [12]. The glow curve is characteristic of the different trap levels that lie in the band gap of a material. A reliable dosimetric study of a thermoluminescent material should be based on a good knowledge of its

(C) N.G. DEBELO, S. HAILEMARIAM, 2020

174 kinetic parameters that include the trap depth (E), order of kinetics (b), and frequency factor (s). The study of relatively deep trapping-defect states in various phosphors, as well as the TL dating of solid-state materials, is closely related to the position of the trapping levels within the forbidden gap [3-10].

The annealing treatment is required to optimize the TL characteristics of phosphor. The annealing parameters like temperature, duration, and atmosphere critically affect the luminescent behavior of phosphor. The annealing is used with TL materials to establish the background (i.e., the TL signal at zero radiation dose) and the sensitivity (i.e., the TL signal per unit radiation dose) of the material and to maintain the stability of these parameters. The high-temperature pre-irradiation annealing restores and standardizes the TL characteristics by erasing the accumulated radiation damage and dispersing the impurity ions to their original states. The low-temperature

ISSN 2071-0194. Ukr. J. Phys. 2020. Vol. 65, No. 2 
annealing reduces the low-temperature peaks to a negligible level compared with the stable dosimetric peaks $[11-15]$.

The annealing temperature critically affects the luminescent behavior of a material, and the annealing brings about an enhancement or decline in the intensity of TL glow peaks of many $\mathrm{TL}$ materials [4-8]. Particularly, in this study of a $\mathrm{KY}_{3} \mathrm{~F}_{10}: \mathrm{Ho}^{3+}$ phosphor powder, we observed an enhancement in its TL intensity following the thermal annealing and a shift of the temperature of each TL peak to the higher temperature region. The TL study and the effect of a thermal treatment of this commercial phosphor are not yet investigated. A change in the trap depth location after the thermal treatment is of our particular interest, because of its great impact on the band gap engineering of this phosphor. The emission wavelength from this phosphor can be tuned following a change in the trap depth position within the band gap [9-11].

It is important to understand the influence of thermal treatments on the TL properties of a crystal. In this work, the effect of the thermal annealing on the trap depth and TL peak positions of a thermoluminescent $\mathrm{KY}_{3} \mathrm{~F}_{10}: \mathrm{Ho}^{3+}$ phosphor powder is presented for the first time using the variable heating rate method (VHR). This study shows that the thermal annealing affects the TL peak temperatures and the level of the trap below the edge of the conduction band.

Moreover, this study focuses on the thermal treatment of a commercially obtained $\mathrm{KY}_{3} \mathrm{~F}_{10}: \mathrm{Ho}^{3+}$ phosphor powder in air. So, the treatments in various gases and vacuum should be further investigated.

\section{Experimental}

A commercially obtained $\mathrm{KY}_{3} \mathrm{~F}_{10}: \mathrm{Ho}^{3+}$ standard phosphor powder (UK) was annealed at temperatures of 400,500 , and $600{ }^{\circ} \mathrm{C}$ for one hour in air. The TL glow curves of this phosphor powder annealed at different temperatures at different heating rates are then recorded and compared with that of the unannealed one. A UV source was used for the TL excitation prior to the heating. TL measurements were obtained by a TL reader of the TL1009I type offered by Nucleonix systems Pvt. Ltd., India interfaced to a PC, where the TL signals were analyzed. Samples were heated from 0 to $400{ }^{\circ} \mathrm{C}$ at various heating rates and for

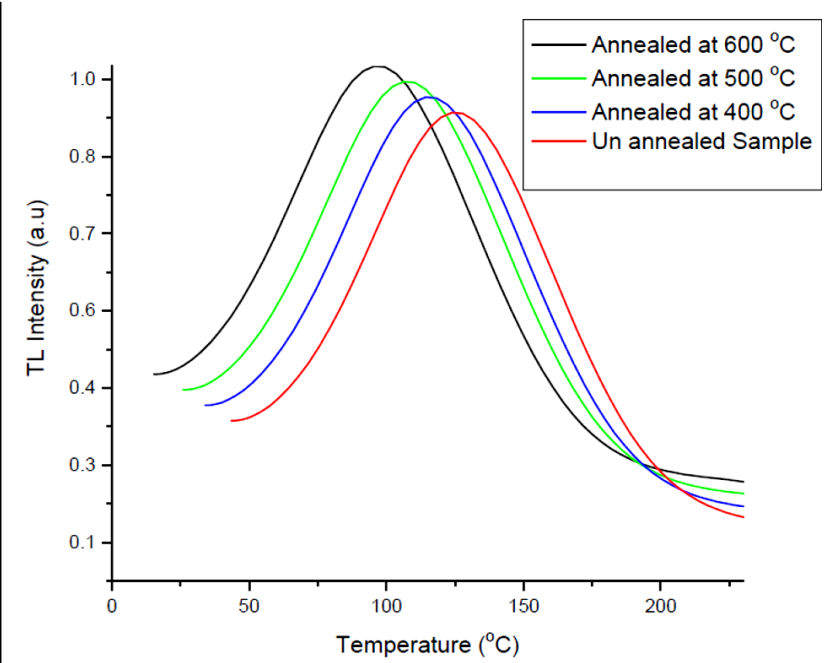

Fig. 1. TL glow curves for $\mathrm{KY}_{3} \mathrm{~F}_{10}: \mathrm{Ho}^{3+}$ phosphor samples annealed at different temperatures

10 minutes of an UV dose. The effect of the thermal annealing on the trap level and TL sensitivity of a phosphor powder was then investigated. TL measurements were done immediately after stopping the UV exposure. The level of the trap within the band gap of a phosphor powder was evaluated for each annealing temperature. The structure of the sample was also studied by X-ray diffraction (XRD) using a Bruker D8 advance X-ray diffractometer operating at $40 \mathrm{kV}$ and $4 \mathrm{~mA}$ using $\mathrm{Cu} K \alpha=0.15406 \mathrm{~nm}$. The morphology was studied using a high-resolution Transmission Electron Microscope (TEM).

\section{Results and Discussion}

The TL spectra were taken following the furnace annealing at different temperatures for $1 \mathrm{~h}$ in air. After the thermal annealing, changes in the TL glow curves were observed. Figure 1 shows the TL glow curves of $\mathrm{KY}_{3} \mathrm{~F}_{10}: \mathrm{Ho}^{3+}$ phosphor samples annealed at different temperatures. All the TL measurements were taken at a heating rate of $1{ }^{\circ} \mathrm{C} / \mathrm{s}$ after the irradiation with the same UV dose for $10 \mathrm{~min}$. It is found that the TL intensity increases with the annealing temperature of the samples.

We assign this to the fact that a higher annealing temperature minimizes the residual TL signal by emptying the high-temperature traps and restores the original sensitivity and the glow curve structure. The initial nonzero value of the TL intensity is attributed 


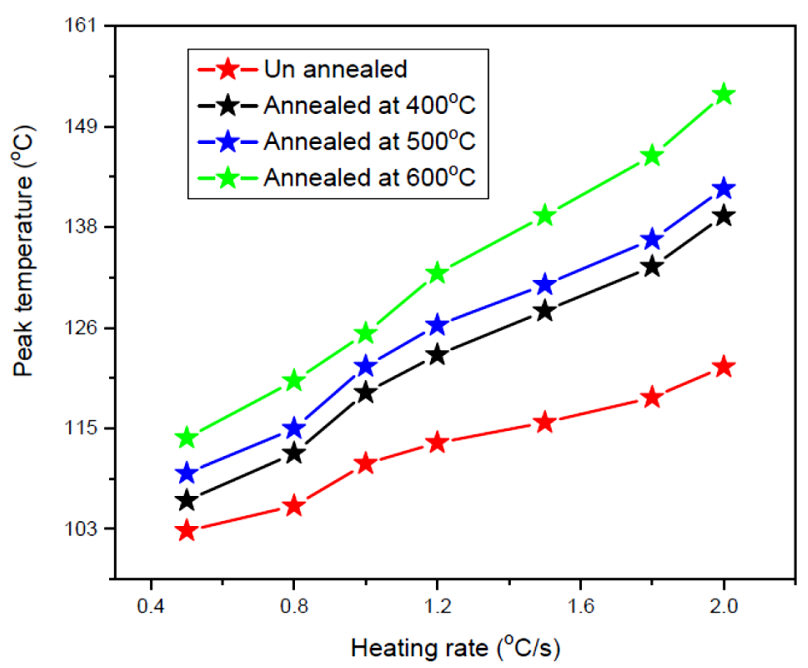

Fig. 2. Effect of the annealing on the peak temperatures of the glow curves. The measurements were taken for various heating rates



Fig. 3. Graph of $\frac{1}{k T_{M}}$ versus $\ln \left(\frac{T_{M}^{2}}{\beta}\right)$ at an annealing temperature of $400{ }^{\circ} \mathrm{C}$

to the phenomena of fluorescence during the UV irradiation. The effect of a thermal treatment on the peak temperatures of the glow curves was also analyzed for various heating rates and shown in Fig. 2.

This figure clearly shows that the annealing process affects the peak temperatures of glow peaks. In all variations, the peak temperatures of all glow peaks of the annealed $\mathrm{KY}_{3} \mathrm{~F}_{10}: \mathrm{Ho}^{3+}$ phosphor are higher than that of the unannealed one. In addition, the shift in the peak temperature of glow curves to the higher temperature side increases with the heating rate.
It has been reported that the thermal annealing has also a clear effect on the position of the trap within the band gap [13-15]. Let us now analyze the evolution of the TL maximum with the heating rate in order to determine the level of the trap beneath the edge of the conduction band. For this purpose, we performed a variable heating rate (VHR) analysis that considers how the traps are emptied at different heating rates, while all other parameters are held constant. As the heating rate increases, there is an observed shift in the position of the TL maximum $T_{M}$ toward higher temperatures (Figs. 1 and 2 ). The heating rate $\beta$ can be related to the $T_{M}$ of its corresponding peak using the equation [7-9]:

$\frac{E}{k_{M}}=\operatorname{sexp}\left(-\frac{E}{k T_{M}}\right)$

where $k$ is the Boltzmann constant (in units of $\mathrm{eV} / \mathrm{K}$ ), and $E$ is the activation energy (in units of $\mathrm{eV}$ ). A change in the linear heating rate $\beta$ results in a change of the temperature $T_{M}$ of the maximum TL intensity of the peak: faster heating rates produce a shift in the temperature toward higher values of $T_{M}$, as shown in Fig. 1. By means of the VHR method, the trap depth (the activation energy) was derived from the variation of $\ln \left(\frac{T_{M}^{2}}{\beta}\right)$ as a function of $\frac{1}{k T_{M}}$ to see how the annealing process affects the level of the trap within the band gap. When $\ln \left(\frac{T_{M}^{2}}{\beta}\right)$ is plotted against $\frac{1}{k T_{M}}$, the resulting graph consists of a straight line with slope $E$ and intercept (on $\ln \left(\frac{T_{M}^{2}}{\beta}\right)$ ) axis $\ln \left(\frac{E}{S k}\right)$, as shown in Fig. 3. The calculated values of $E$ are 0.92 for the unannealed sample, 0.54 for a sample annealed at $400{ }^{\circ} \mathrm{C}, 0.52$ for a sample annealed at $500{ }^{\circ} \mathrm{C}$ and 0.44 for a sample annealed at $600{ }^{\circ} \mathrm{C}$.

The comparison of the unannealed and annealed phosphor powders shows that the annealing process shifts the peak temperatures of the glow curves; the peak temperatures of the glow peaks of the annealed phosphor being higher than that of the unannealed phosphor. One of the reasons for shifts in the peak temperatures after the annealing can be due to the cluster formation. The formation of the clusters of traps instead of randomly distributed defects causes a variation in the kinetics of the trapping and recombination processes [1-5].

The calculated data on $\ln \left(\frac{T_{M}^{2}}{\beta}\right)$ and $\frac{1}{k T_{M}}$ are shown in Table for various annealing temperatures. Another 
cause for an variation in the peak temperatures after the annealing can be the removal and creation of defects as a result of the annealing [10-15]. For the sake of comparison, the TL kinetic parameters are also determined using the initial rise method. Using this method, the calculated values of $E$ are 0.90 for the unannealed sample, 0.51 for a sample annealed at $400{ }^{\circ} \mathrm{C}, 0.54$ for a sample annealed at $500{ }^{\circ} \mathrm{C}$, and 0.42 for a sample annealed at $600{ }^{\circ} \mathrm{C}$. This is in a good agreement with the results obtained from the VHR method.

\section{Structural and Morphological Studies}

Figure 4 shows the XRD pattern of the sample. The crystal structure and the phase purity of the material is obtained, and all the obtained diffraction peaks were indexed and assigned to a monoclinic phase with unit cell dimensions (in Angstr'om) $a=10.41, b=$ $=6.73, c=12.46$. The pattern was compared with the Joint Committee on Powder Diffraction Standards (JCPDS) card No. 21-1458. The prominent displayed peaks correspond to (hkl) values: (200), (100), (220),(321), (400), (422), (404), (426), and (624). The width of the peak increases, as the crystallite size decreases. The average crystallite size of the prepared powder was determined from Scherrer equation $[2,8]$ which is given by

$D=\frac{0.9 \lambda}{\beta \cos \theta}$,

where $D$ is the crystallite size, $\lambda$ is the $\mathrm{X}$-ray wavelength $(0.15406 \mathrm{~nm}), \beta$ is the FWHM, and $\theta$ is the

$\frac{1}{k T_{M}}$ versus $\ln \left(\frac{T_{M}^{2}}{\beta}\right)$ for unannealed

and annealed samples at different temperatures

\begin{tabular}{|l|c|c|c|c|c|c|c|}
\hline \multicolumn{2}{|c|}{$\begin{array}{c}\text { Unannealed } \\
\text { sample }\end{array}$} & $\begin{array}{c}\text { Sample } \\
\text { annealed } \\
\text { at } 400^{\circ}\end{array}$ & \multicolumn{2}{c|}{$\begin{array}{c}\text { Sample } \\
\text { annealed } \\
\text { at } 500^{\circ}\end{array}$} & \multicolumn{2}{c|}{$\begin{array}{c}\text { Sample } \\
\text { annealed } \\
\text { at } 600^{\circ}\end{array}$} \\
\hline$\frac{1}{k T_{M}}$ & $\ln \left(\frac{T_{M}^{2}}{\beta}\right)$ & $\frac{1}{k T_{M}}$ & $\ln \left(\frac{T_{M}^{2}}{\beta}\right)$ & $\frac{1}{k T_{M}}$ & $\ln \left(\frac{T_{M}^{2}}{\beta}\right)$ & $\frac{1}{k T_{M}}$ & $\ln \left(\frac{T_{M}^{2}}{\beta}\right)$ \\
\hline 31.985 & 14.35 & 31.49 & 14.38 & 31.72 & 14.31 & 31.19 & 14.43 \\
31.77 & 13.82 & 31.12 & 13.87 & 31.32 & 13.85 & 30.72 & 13.89 \\
31.404 & 13.59 & 30.61 & 13.66 & 30.82 & 13.63 & 30.35 & 13.59 \\
31.23 & 13.39 & 30.28 & 13.47 & 30.52 & 13.45 & 29.88 & 13.49 \\
31.067 & 13.15 & 29.97 & 13.23 & 30.17 & 13.16 & 29.44 & 13.28 \\
30.86 & 12.95 & 29.25 & 12.95 & 29.45 & 12.94 & 28.57 & 13.01 \\
\hline
\end{tabular}

ISSN 2071-0194. Ukr. J. Phys. 2020. Vol. 65, No. 2

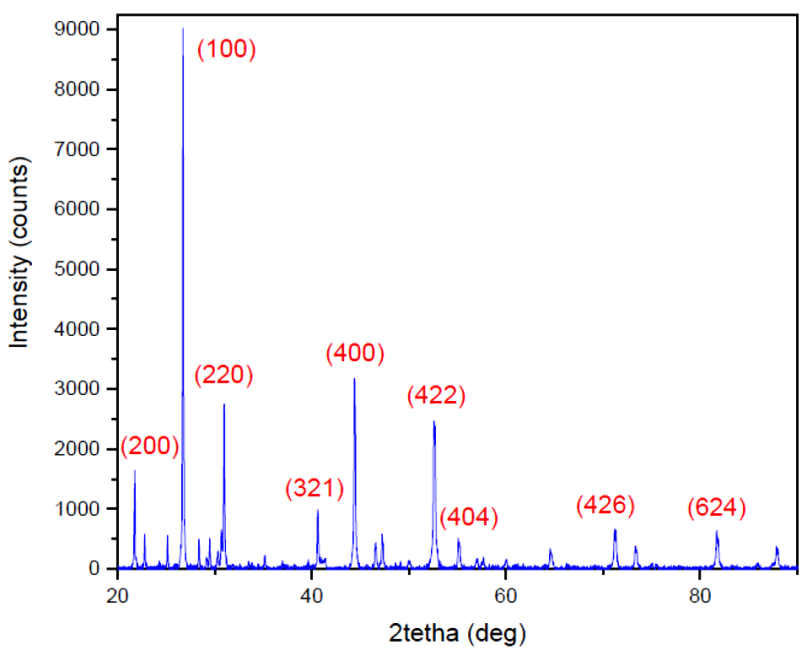

Fig. 4. XRD pattern of a $\mathrm{KY}_{3} \mathrm{~F}_{10}: \mathrm{Ho}^{3+}$ phosphor powder

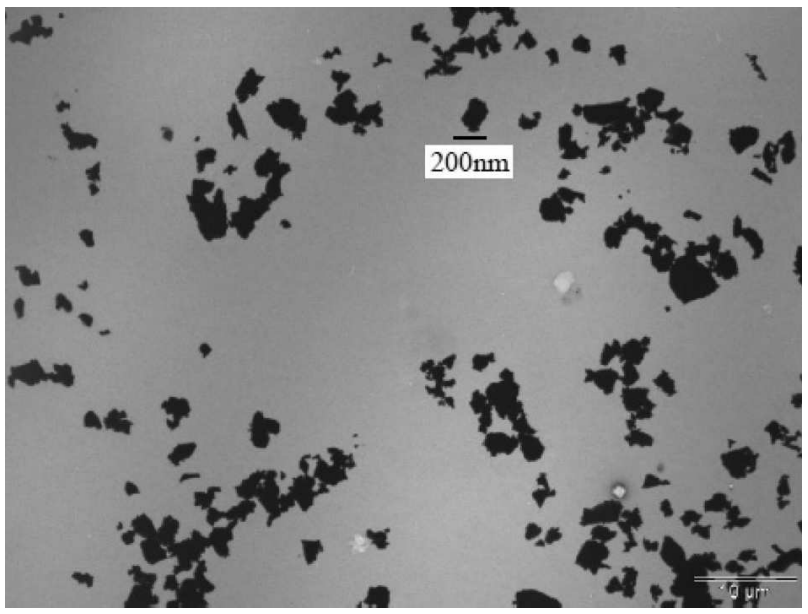

Fig. 5. TEM image of a $\mathrm{KY}_{3} \mathrm{~F}_{10}: \mathrm{Ho}^{3+}$ phosphor powder

diffraction angle. The average crystallite size of the sample is $182 \mathrm{~nm}$.

The transmission electron microscopy (TEM) image of the sample is also shown in Fig. 5. TEM image indicates that the particles of $\mathrm{KY}_{3} \mathrm{~F}_{10}: \mathrm{Ho}^{3+}$ extend up to several hundreds of nanometers in size. This result is in a good agreement with the average size obtained using the XRD result.

\section{Conclusion}

In this work, the study of the effects of the annealing on TL peak positions and trap depths of a commercially obtained $\mathrm{KY}_{3} \mathrm{~F}_{10}: \mathrm{Ho}^{3+}$ phosphor powder is carried out within the variable heating rate (VHR) 
method. We have shown that the thermal treatments affect the TL peak temperatures and alter the trap depths. This effect of annealing on the trap depth within the band gap of $\mathrm{KY}_{3} \mathrm{~F}_{10}: \mathrm{Ho}^{3+}$ is studied in details. It is observed that the activation energy shifts toward the conduction band edge after the thermal treatment in such a way that it decreases with increase in the annealing temperature. An increment in the TL intensity and a shift of the TL peaks toward the higher temperature region following the thermal treatment are also observed. The XRD pattern of the sample shows a monoclinic structure match with JCPDS card No. 21-1458.

1. F.O. Ogundare, L.A. Hussain, F.A. Balogun. Heating rate effects on the thermoluminescence of fluorite. Radiat. Meas. 40, 60 (2012).

2. N.G. Debelo, F.B. Dejene, K.T. Roro. Thermally stimulated luminescence of $\mathrm{Y}_{2} \mathrm{SiO}_{5}: \mathrm{Ce}^{3+}$. Int. J. Thermophys. 37, 69 (2016).

3. Vo Van Hoang. Heating rate effects in simulated liquid $\mathrm{Al}_{2} \mathrm{O}_{3}$. Eur. Phys. J. Appl. Phys. 33, 69 (2006).

4. Y. Parganiha, V. Dubey, J. Kaur, R. Shrivastava. $\mathrm{YAlO}_{3}: \mathrm{Ce}^{3+}$ powders: Synthesis, characterization, thermoluminescence and optical studies. Superlattices $\mathrm{Mi}$ crostruct. 77, 152 (2015).

5. N. Gemechu, T. Abebe. Structural characterization and thickness profile of pulsed laser-deposited $\mathrm{KY}_{3} \mathrm{~F}_{10}: \mathrm{Ho}^{3+}$ thin films pulsed laser deposition of thin films. Ukr. J. Phys 63, 182 (2018).

6. J. Manam, S. Isaac. Preparation, characterization and thermally stimulated luminescence of $\mathrm{ZnO}$ nanophosphor. Ind. J. Phys. 83, 1407(2009).

7. J. Chandler, S. Sholom, S. McKeever, H. Hall. Thermoluminescence and phototransferred thermoluminescence dosimetry on mobile phone protective touch screen glass. J. Appl. Phys. 126, 074901 (2019).

8. N. Debelo, T. Senbeta, B. Mesfin, F. Dejene. Synthesis and luminescence properties of $\mathrm{Ca}_{3} \mathrm{Y}_{2}\left(\mathrm{Si}_{3} \mathrm{O}_{9}\right)_{2}: \mathrm{xCe}^{3+}$ nanophosphor. J. Mater. Sci.: Mater. Electron. 28, 1 (2017).

9. V. Dubey, J. Kaur, S. Agrawal, N. Suryanarayana, K. Murthy. Effect of $\mathrm{Eu}^{3+}$ concentration on photolumines- cence and thermoluminescence behavior of $\mathrm{YBO}_{3}: \mathrm{Eu}^{3+}$ phosphor. Superlattices Microstruct. 67, 156 (2014).

10. C.R. Ronda. Luminescence from Theory to Applications (Wiley, 2007) [ISBN: 978-3-527-31402-7].

11. N.G. Debelo, F.B. Dejene, K.T. Roro. Pulsed laser deposited $\mathrm{KY}_{3} \mathrm{~F}_{10}: \mathrm{Ho}^{3+}$ thin films: Influence of target to substrate distance. Mater. Chem. Phys. 190, 62 (2017).

12. P. Seth. S. Aggarwal, S. Rao. Thermoluminescence study of rare earth ion $\left(\mathrm{Dy}^{3+}\right)$ doped $\mathrm{LiF}: \mathrm{Mg}$ crystals grown by EFG technique. J. Rare Earth. 30, 241 (2012).

13. J.M. Kalita, M.L. Chithambo. Photo transferred thermoluminescence and thermally-assisted optically stimulated luminescence dosimetry using $\alpha-\mathrm{Al}_{2} \mathrm{O}_{3}: \mathrm{C}, \mathrm{Mg}$ annealed at $1200{ }^{\circ}$ C. J. Lumin. 205, 1 (2019).

14. U. Pal. Thermoluminescence properties of $\mathrm{ZnO}$ and $\mathrm{ZnO}: \mathrm{Yb}$ nanophosphors. Appl. Phys. Lett. 89, 183118 (2006).

15. N. Debelo, F. Dejene, K. Roro, T. Senbeta, B. Mesfin, T. Abebe, L. Mostert. Enhanced emission and improved crystallinity of $\mathrm{KY}_{3} \mathrm{~F}_{10}: \mathrm{Ho}^{3+}$ thin films grown at high deposition temperature using pulsed laser deposition technique. J. Electron. Mater. 47, 2617 (2018).

Received 07.04.19

Н.Г. Дебело, С. Хейлемаріам

ВПЛИВ ВІДПАЛУ НА ІНТЕНСИВНІСТЬ

ТЕРМОЛЮМІНЕСЦЕНЦІЇ $\mathrm{KY}_{3} \mathrm{~F}_{10}: \mathrm{Ho}^{3+}$

$\mathrm{P}$ е $з$ ю м е

Досліджено вплив відпалу на криві світіння під час термолюмінесценції сполуки $\mathrm{KY}_{3} \mathrm{~F}_{10}: \mathrm{Ho}^{3+}$ промислового виробництва, і проведено порівняння з результатами для невідпаленого зразка. Відпал проводився при температурах 400 , 500 i $600{ }^{\circ} \mathrm{C}$. Розраховано один з кінетичних параметрів термолюмінесценції, енергія активації (глибина пастки), для відпаленого і невідпаленого зразків, з використанням методу змінної швидкості нагріву. Результати показали, що відпал впливає на інтенсивність світіння при термолюмінесценції. 3 ростом температури відпалу максимуми кривих термолюмінесценції зміщуються в бік більш високих температур. Чим вища температура відпалу, тим нижче положення рівня пастки відносно краю зони провідності. Рентгенографія показує наявність моноклінної структури з параметрами елементарної комірки (в $\AA$ ) $a=10,41, b=6,73$, $c=12,46$, відповідними JCPDS мапі No. 21-1458. 